\title{
ANALISIS PERAMALAN PENJUALAN AIR MINUM DALAM KEMASAN 240mI PADA PT TRIJAYA TIRTA DARMA (GREAT) DENGAN METODE SINGLE MOVING AVARAGE DAN EXPONENTIAL SMOOTHING
}

\author{
Dita Meliana*, Suharto, Putri Endah Suwarni \\ Progam Studi Teknik Industri Fakultas Teknik \\ Universitas Tulang Bawang Lampung \\ J1. Gajah Mada No. 34 Kotabaru Bandar Lampung \\ Penulis Korespodensi :ditameliana65@gmail.com
}

\begin{abstract}
Companies engaged in the field of product sales or distribution services, definitely want success in their activities in the future. This shows that every company always strives to continue to be able to develop in its business field in the future. Forecasting is a method for estimating a value in the future by using past data. Forecasting can also be interpreted as an art and science to predict future events. Researchers conducted a study by taking a location in PT Trijaya Tirta Dharma bottled water company. The author discusses forecasting sales of $240 \mathrm{ml}$ bottled water using two methods, namely Single Moving Average and Exponential Smoothing. The author compares the smallest error rate, the forecasting method chosen is Exponential Smoothing. For the Exponential Smoothing method, the results obtained using alpha 0.2 are for February of 195,767, March 197905, April 199,527, May 213,661, June 227,287, July 238,295, August 246,234, September 263,600, October 256,923, November 266,857, December 238,762. Then the forecast is MFE 22466,593, MAD 22466.593, MSE 55522225874, MAPE $2 \%$.
\end{abstract}

Keywords: Forecasting and sales; Single Moving Average; Exponential Smoothing

\section{Pendahuluan}

Pada saat ini hampir semua perusahaan yang bergerak di bidang industri dihadapkan pada suatu tantangan, yaitu adanya tingkat persaingan yang semakin ketat. Hal ini mengharuskan perusahaan untuk dapat merencanakan semua parameter produksi dengan baik, termasuk kapasitas produksi agar dapat memenuhi permintaan pasar dengan tepat waktu dan dengan jumlah yang sesuai, sehingga diharapkan keuntungan perusahaan akan meningkat (Kurniawan dan Wiwi, 2013). Peramalan atau forecasting merupakan teknik atau cara kuantitatif dalam memperkirakan apa yang akan terjadi pada masa mendatang, dan tentunya membutuhkan data-data masa lampau sebagai acuan atau data historis (Lestari dan Wahyuningsih, 2012). Salah satu manfaat peramalan penjualan adalah dapat memperkirakan penjualan secara akurat dari waktu ke waktu sehingga dapat dibuat rencana produksi yang sesuai dengan perkiraan penjualan (Munawar,2003). Data peramalan penjualan dapat digunakan sebagai dasar perencanaan produksi untuk mencegah terjadinya over production yang mengakibatkan perusahaan mengalami idle capital maupun under production yang menyebabkan perusahaan kehilangan kesempatan dalam menjual hasil produksinya. Dengan adanya peramalan tersebut, maka perusahaan dapat mencapai tujuan perusahaan serta pengambilan keputusan dalam produksinya

Air minum dalam kemasan (AMDK) mempunyai peranan yang sangat penting didalam kehidupan bermasyarakat saat ini. Disaat kebutuhan air yang benar-benar layak semakin sulit didapat, berbagai jenis air minum dalam kemasan banyak ditawarkan oleh industri air minum baik yang dari skala kecil hingga skala yang besar. 
PT Trijaya Tirta Dharma adalah produsen air minum dalam kemasan yakni dengan merek Great, berdiri pada tanggal 14 Juni 2000. Kualitas merupakan salah satu faktor penting yang harus dijaga oleh PT Trijaya Tirta Dharma untuk menjaga loyalitas konsumen sehingga PT Trijaya Tirta Dharma menghasilkan produk air minum Great yang diproduksi dengan higienis dan steril serta memenuhi standar SNI sehingga menghasilkan produk yang berkualitas tinggi.

Peramalan adalah seni atau ilmu untuk memperkirakan kejadian di masa depan. Hal ini dapat dilakukan dengan melibatkan pengambilan data historis dan memproyeksikannya ke masa mendatang dengan suatu bentuk model sistematis, Atau bisa juga dengan menggunakan kombinasi model matematis yang disesuaikan dengan pertimbangan yang baik dari seorang manajer (Render \& Heizer, 2009). Peramalan biasanya diklasifikasikan berdasarkan horizon waktu masa depan yang dilingkupinya. Peramalan biasanya diklarifikasikan berdasarkan horizon waktu masa depan yang dilingkupinya. Peramalan diperlukan perhitungan yang akurat sehingga diperlukan peramalan yang tepat. Pada dasarnya terdapat dua pendekatan umum untuk mengatasi semua model keputusan untuk meramal (Nasution, 2008):

1. Peramalan kualitatif yaitu peramalan yang menggabungkan faktor faktor seperti intuisi pengambilan keputusan, emosi, pengalaman pribadi, dan system nilai

2. Peramalan kuantitatif yaitu peramalan yang menggunakan satu atau lebih model matematis dengan data masa lalu dan variabel sebab akibat untuk meramalkan permintaan. Ada lima metode peramalan kuantitatif, yaitu metode pendekatan naif, metode rata-rata bergerak, metode penghalusan eksponential, penghalusan tren, dan regresi linear.

Untuk memenuhi kebutuhan pasar maka PT Trijaya Tirta Dharma harus mengetahui berapa peramalan penjualan yang akan datang sehingga perusahaan dapat memproduksi barang yang dihasilkan, karena dengan mengetahui beberapa penjualan pada periode berikutnya, perusahaan dapat memproduksi barang secara tidak berlebihan. Tujuan dari penelitian ini adalah untuk mengetahui peramalan penjualan produk air minum kemasan gelas tahun 2018 dan 2019 di PT.
Trijaya Tirta Darma (Great) dengan metode Single Moving Avarage dan Exponential Smoothing, mengetahui forcast error dari hasil peramalan dengan ke dua metode tersebut dan untuk mengetahui metode peramalan yang tepat dalam menentukan besarnya penjualan produk air minum kemasan gelas di PT. Trijaya Tirta Darma (Great).

\section{Metode Penelitian}

1. Metode Moving Average

Rata-rata bergerak (Moving Average) adalah suatu metode peramalan yang dilakukan dengan mengambil sekelompok nilai pengamatan, mencari nilai rata-rata tersebut sebagai ramalan untuk periode yang akan dating (Subagyo, 2008). Metode Moving Average mempunyai

Karakteristik khusus yaitu ;

1. Untuk menentukan ramalan pada periode yang akan datang memerlukan data historis selama jangka waktu tertentu. Misalnya, dengan 3 bulan moving average, maka ramalan bulan ke 5 baru dibuat setelah bulan ke 4 selesai/berakhir. Jika bulan moving averages bulan ke 7 baru bisa dibuat setelah bulan ke 6 berakhir.

2. Semakin panjang jangka waktu moving average, efek pelicinan semakin terlihat dalam ramalan atau menghasilakan moving average yang semakin halus.

Persamaan matematis single moving averages adalah sebagai berikut:

$$
\begin{gathered}
M t=F t+1(1) \\
=\frac{Y t+Y t-1+Y t-2+\ldots+Y t-n+1}{n}
\end{gathered}
$$

$\mathrm{n} \quad=$ Jumlah batas dalam moving average

Dalam model moving average dapat dilihat bahwa bahwa semua data observasi memiliki bobot yang sama yang membentuk rata-ratanya. Padahal data observasi terbaru seharusnya memiliki bobot yang lebih besar dibandingkan dengan data observasi dimasa lalu. Hal ini dipandang sebagai kelemahan dalam metode moving average. Tujuan utama dari penggunaaan rata-rata bergerak adalah untuk menghilangkan atau mengurangi acakan dalam deret waktu. Teknik rata-rata bergerak dalam deret waktu terdiri dari pengambilan suatu kumpulan nilai-nilai yang diobservasi, mendapatkan rata-rata dari nilai ini, dan 
kemudian menggunakan nilai rata-rata tersebut sebagai ramalan untuk periode yang akan datang (Assauri, 1984). Peramalan dengan teknik moving average melakukan perhitungan terhadap nilai data yang paling baru sedangkan data yang tua/lama akan dihapus. Nilai ratarata dihitung berdasarkan jumlah data, yang angka rata-rata bergeraknya ditentukan dari harga 1 sampai nilai $\mathrm{N}$ data yang dimiliki.

1. Metode Rata-rata Bergerak Tunggal (Single Moving Averages).

Metode rata-rata bergerak tunggal menggunakan sejumlah data aktual permintaan yang baru untuk membangkitkan nilai ramalan untuk permintaan di masa yang akan datang. Metode ini akan efektif diterapkan apabila kita dapat mengasumsikan bahwa permintaan pasar terhadap produk akan tetap stabil sepanjang waktu (Gaspersz, 2005:87). Bila permintaan berubah secara signifikan dari waktu ke waktu, ramalan harus cukup agresif dalam mengantisipasi parubahan tersebut, sehingga nilai $\mathrm{N}$ yang kecil akan lebih cocok dipakai. Sebaliknya, bila permintaan cenderung stabil selama jangka waktu yang panjang, sebaiknya dipakai nilai $\mathrm{N}$ yang besar (Nasution, 2005:247). Secara sistematis, penulisan persamaan Single Moving Averages adalah sebagai berikut:

$$
F_{t-1}=\frac{X_{t}+X_{t-1}+X_{t-2}+\cdots+X_{t-N+1}}{N}
$$

Keterangan:

$F t-1=$ ramalan untuk periode ke $\mathrm{t}+1$

$X t=$ data untuk periode ke $\mathrm{t}$

$\mathrm{N}=$ jangka waktu rata-rata bergerak

\section{Exponentials Smoothing}

Metode ini digunakan untu peramalan jangka pendek. Model mengasumsikan bahwa data berfluktuasi di sekitar nilai mean yang tetap, tanpa trend atau pola pertumbuhan konsisten. Tidak seperti Moving Average, Exponential Smoothing memberikan penekanan yang lebih besar kepada time series saat ini melalui penggunaan sebuah konstanta smoothing (penghalus). Konstanta smoothing mungkin berkisar dari 0 ke 1 . Nilai yang dekat dengan 1 memberikan penekanan terbesar pada nilai saat ini sedangkan nilai yang dekat dengan
0 memberi penekanan pada titik data sebelumnya (Herjanto, 2009).

Menurut Garpersz (2005:97) untuk penetapan nilai $\alpha$ yang diperkirakan tepat, kita dapat menggunakan panduan berikut:

1. Apabila pola historis dari data aktual permintaan sangat bergejolak atau tidak stabil dari waktu ke waktu, kita memilih nilai $\alpha$ yang mendekati satu. Biasanya dipilih nilai $\alpha=0,9$; namun pembaca dapat mencoba nilai-nilai $\alpha$ yang lain yang mendekati satu, katakanlah: $\alpha=0,8 ; 0,95$; 0,99, dan lain-lain, tergantung pada sejauh mana gejolak dari data itu. Semaikin bergejolak, nilai $\alpha$ yang dipilih harus semakin tinggi menuju ke nilai satu.

2. Apabila pola historis dari data aktual permintaan tidak berfluktuasi atau relatf stabil dari waktu ke waktu, kita memilih nilai $\alpha$ yang mendekati nol. Biasanya dipilih nilai $\alpha=0,1$; namun pembaca dapat mencoba nilai- nilai $\alpha$ yang lain yang mendekati satu, katakanlah: $\alpha=0,2 ; 0,15$; 0,05 , dan lain-lain, tergantung pada sejauh mana kestabilan dari data itu. Semaikin stabil, nilai $\alpha$ yang dipilih harus semakin kecil menuju ke nilai nol.

Secara metematis, persamaan penulisan Eksponensial adalah sebagai berikut:

$$
S t=\alpha * X t+(1-\alpha) * S t-1
$$

Rumus untuk Simple exponential smoothing adalah sebagai berikut:

Dimana:

$\mathrm{S}_{\mathrm{t}}=$ peramalan untuk periode $\mathrm{t}$.

$X_{t}+(1-\alpha)=$ nilai aktual time series

$\mathrm{F}_{\mathrm{t}-1}=$ peramalan pada waktu $\mathrm{t}-1$ (waktu sebelumnya)

$\alpha=$ konstanta perataan antara 0 dan 1

Metode Exponential Smoothing cocok untuk data yang bergerak acak ke atas dan ke bawah secara terus menerus berarti tidak ada tren maupun musiman.

Ada empat model dari metode exponential smoothing yang mengakomodasi asumsi mengenai trend dan musiman:

1. Simpel (tunggal), model ini mengasumsikan bahwa seri 
pengamatan tidak memiliki trend dan variasi musiman.

2. Holt, model ini mengasumsikan bahwa seri pengamatan memiliki trend linier namun tidak memiliki variasi musiman.

3. Winters, model ini mengasumsikan bahwa seri pengamatan memiliki trend linier dan variasi musiman.

4. Custom, model ini memungkinkan untuk melakukan penetapan komponen trend dan variasi musiman.

Ada pula ukuran-ukuran ketepatan lain yang sering digunakan untuk mengetahui ketepatan suatu metode peramalan dalam memodelkan data deret waktu, yaitu nilai MAPE (Mean Absolute Percentage Error), MSE (Mean Squared Error), MAD (Mean Absolute Deviation)

1. Rata-rata persentase kesalahan absolut (Mean Absolute Persentage Error = MAPE)

MAPE merupakan ukuran kesalahan relatif, MAPE biasanya lebih berarti bila dibandingkan dengan MAD karena MAPE menyatakan persentase kesalahan hasil peramalan terhadap permintaan aktual selama periode tertentu yang akan memberikan informasi persentase kesalahan terlalu tinggi atau terlalu rendah. Secara sistematis, MAPE dinyatakan sebagai berikut:

$$
\begin{aligned}
M A P E & =\frac{100}{N} \sum_{t=1}^{N} \frac{\left(Y t-Y^{\prime} t\right)}{Y t} \\
Y t & =\text { Nilai observasi } \\
Y^{\prime} \mathrm{t} & =\text { Nilai peramalan }
\end{aligned}
$$

1. Rata-rata deviasi mutlak (Mean Absolute Deviation = MAD)

MAD merupakan rata-rata kesalahan mutlak selama periode waktu tertentu tanpa memperhatikan apakah hasil peramalan lebih besar atau lebih kecil dibandingkan dengan faktanya. Secara sistematis, MAD dirumuskan sebagai berikut

$$
\begin{gathered}
M A D=\sum \frac{\left(Y-Y^{\prime} t\right)}{n} \\
Y t=\text { nilai observasi } \\
Y^{\prime} t=\text { nilai peramalan }
\end{gathered}
$$

2. Cara lain untuk menghindari penyimpangan nilai positif dan penyimpangan negatif saling meniadakan adalah dengan mengkuadratkan nilai kesalahan tersebut. MSE merupakan ukuran penyimpangan ramalan dengan merataratakan kuadrat error (penyimpangan semua ramalan).

Persamaannya adalah sebagai berikut:

$$
\begin{gathered}
M S E=\sum \frac{\left(Y-Y^{\prime} t\right) 2}{n} \\
Y \mathrm{t}=\text { Nilai observasi } \\
\mathrm{Y}^{\prime} \mathrm{t}=\text { Nilai peramalan }
\end{gathered}
$$

Tujuan optimalisasi statistik seringkali dilakukan untuk memilih suatu model agar nilai MSE minimal, tetapi ukuran ini mempunyai dua kelemahan. Pertama ukuran ini menunjukkan pencocokkan (fitting) suatu model terhadap data historis. Pencocokan seperti ini tidak selalu mengimplikasikan peramalan yang baik. Suatu model yang terlalu cocok (over fitting) dengan deret data berarti sama dengan memasukkan unsur random sebagai bagian proses bangkitan, adalah sama buruknya dengan dengan tidak berhasil mengenai pola non acak dalam data. Kekurangan kedua dalam MSE sebagai ukuran ketepatan model adalah berhubungan dengan kenyataan bahwa metode berbeda akan menggunakan prosedur yang berbeda pula dalam fase pencocokan.

Dalam fase peramalan penggunaan MSE dan MAD sebagai suatu ukuran ketepatan juga dapat menimbulkan masalah. Ukuran ini tidak memudahkan perbandingan antar deret berskala yang berbeda dan untuk selang waktu yang berlainan, karena MSE dan MAD merupakan ukuran absolut yang sangat tergantung pada skala dari data deret waktu. Lagi pula, interpretasi nilai MSE tidak bersifat intuitif, karena ukuran ini menyangkut pengkuadratan sederetan nilai. Karena alasan tersebut dalam hubungan dengan keterbatasan MSE dan MAD sebagai ukuran ketepatan peramalan, maka dipakai ukuran alternatif sebagai salah satu indikasi ketepatan dalam peramalan, yaitu MAPE.

\section{Jenis Penelitian}

Jenis penelitian yang digunakan pada penelitian ini adalah penelitian yang bersifat explanatory (explanatory research) 


\section{Analisis Data}

Dalam bab ini penulis akan menganalisis mengenai peramalan penjualan produk air minum $240 \mathrm{ml}$ untuk memprediksi penjualan pada periode yang akan datang. Dalam perhitungan peramalan penjualan produk penulis menggunakan data penjualan tahun 2019 untuk dianalisis. Sebagai pembuktian penulis menganalisis terlebih dahulu data tahun 2018 untuk diramalkan sebagai pembuktian. Metode yang digunakan penulis adalah Single Moving Avarage dan Exponential Smoothing. Dengan membandingkan hasil peramalan dari kedua metode, diharapkan memperoleh tingkat kesalahan atau eror terkecil, sehingga dapat dijadikan pedoman untuk melakukan peramalan periode mendatang.

\section{Alur Penelitian}

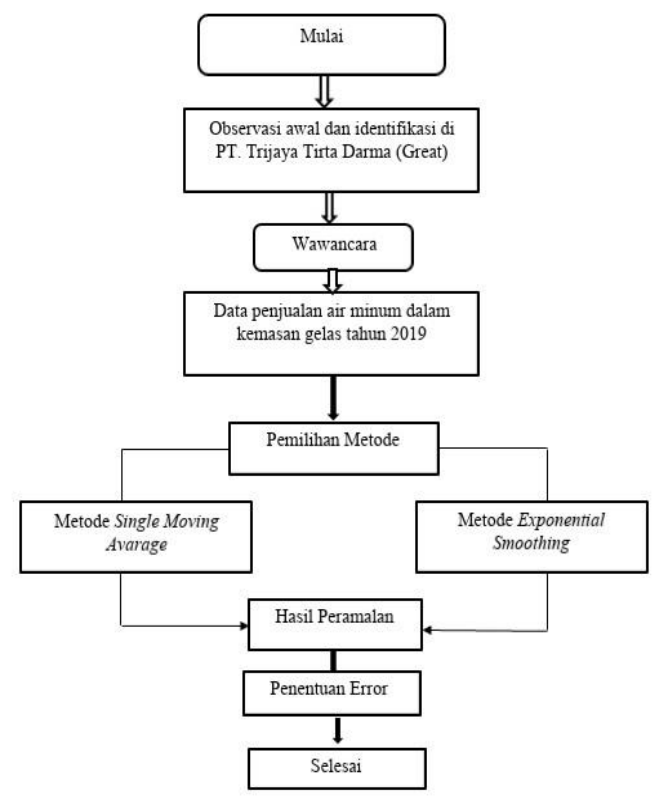

Gambar 1. Alur Penelitian

\section{Hasil Dan Pembahasan}

\section{- Pengujian Data}

Pada data time series yang berbasis waktu, diperlukan pengujian terlebih dahulu sebelum data tersebut diolah, yang disebut uji pola data. Uji pola data intinya adalah menguji apakah dikatakan stasioner atau tidak. Jika pada data terdapat trend, seasonal atau siklis, maka dapat dikatakan data tersebut tidak stasioner. Begitu juga sebaliknya, jika pada data tidak ada trend, seasonal ataukah siklis, maka data tersebut bersifat stasioner. Stasioneritas data penting untuk menentukan metode peramalan apa yang tepat dilakukan. Metode untuk data yang stasioner akan berbeda dengan metode peramalan untuk data yang bersifat tidak stasioner.

Berikutnya, perlu dipastikan bahwa data tersebut memiliki pola trend atau tidak dengan melakukan uji autokorelasi. Dengan begitu data yang stasioner atau data yang tidak stasioner pun dapat diketahui. Dengan uji autokorelasi dapat diketahui grafik autokorelasi sebagai berikut:

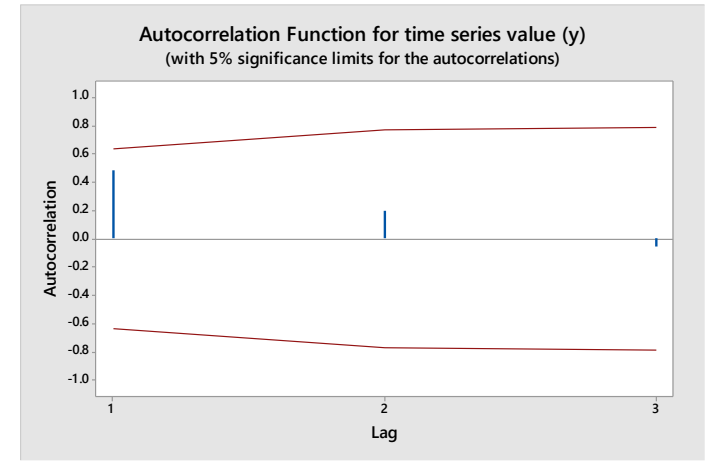

Gambar 2. Grafik Autokorelasi

Dari grafik autokorelasidiatas, terdapat dua garis warna merah. Itu adalah garis upper dan lower dari angka korelasi yang tidak menunjukan adanya autokorelasi. Hal ini ditunjukan dari tidak adanya garis-garis warna biru yang melebihi garis merah yang berada di atas atau di bawah. Dengan demikian dapat disimpulkan tidak ada korelasi sehingga terbukti tidak ada trend dan data bersifat random, serta pada saat bersamaan data tersebut bersifat stasioner. Dengan pola grafik seperti itu dimana data bersifat stasioner, sehingga dilakukan pengolahan data peramalan tersebut dengan menggunakan dua metode peramalan, yaitu : metode peramalan moving average dan single exponential smoothing.

Setelah dilakukan peramalan penjualan produk air minum dalam kemasan $240 \mathrm{ml}$ menggunakan metode Single Moving Average telah didapatkan hasil peramalan periode tahun 2019 yaitu untuk forecast bulan Januari (262.770), Febuari (225.289), Maret (222.525), April (203.748), Mei (228.892), Juni (252.688), Juli (278.104), Agustus (280.702), September (297.794), Oktober (280.425), November (289.959), Desember (221.064). 
Lalu untuk forecast error yang didapat yaitu MFE sebesar 2180.777, MAD sebesar 50250, MSE sebesar 4164474008, MAPE sebesar $25 \%$.

Untuk metode Exponential Smoothing hasil yang didapatkan dengan menggunakan alpha 0.2 yaitu untuk bulan Febuari sebesar (195.767), Maret (197.905), April (199.527), Mei (213.661), Juni (227.287), Juli (238.295), Agustus (246.234), September (263.600), Oktober (256.923), November (266.857), Desember $(238,762)$. Lalu forecast yang didapat yaitu MFE 22.466,593, MAD sebesar 22.466,593, MSE sebesar 55.522.225874, MAPE sebesar $2 \%$.

Untuk metode Exponential Smoothing hasil yang didapatkan dengan menggunakan alpha 0.5 yaitu untuk bulan Febuari sebesar (195.767), Maret (202.613), April (204.315), Mei (237.256), Juni (259.522), Juli (270.924), Agustus (274.457), September (303.761), Oktober (266.989), November (286.791), Desember (206.585). Lalu forecast yang didapat yaitu MFE 7542,72345, MAD sebesar 7542,72345, MSE sebesar 62.581.9448, MAPE sebesar $4 \%$.

Dari hasil peramalan diatas angka angka yang diperoleh maka dipilih metode yang tepat yaitu metode Exponential Smoothing dengan alpha 0.2, karena metode tersebut memiliki tingkat error yang kecil dibandingkan dengan metode yg lain. Peramalan yang baik adalah peramalan yang memiliki tingkat error terkecil.

\section{Kesimpulan}

Berdasarkan analisis hasil dan pembahasan yang telah lakukan, maka dapat disimpulkan sebagai berikut :

1. Jumlah penjualan tahun 2018 dan 2019 berdasarkan metode Single Moving Average dan Exponential Smoothing adalah sebagai berikut :

Tabel 1. Ramalan 2019 dan data actual real metode Single Moving Average

\begin{tabular}{|c|c|c|}
\hline No & $\begin{array}{c}\text { Ramalan penjualan 2019 } \\
\text { menggunakan data 2018 }\end{array}$ & $\begin{array}{c}\text { Data penjualan } \\
\text { 2019 real }\end{array}$ \\
\hline 1 & $262.770,333$ & 194.767 \\
\hline 2 & $122.818,367$ & 210.460 \\
\hline 3 & $173.289,9$ & 206.017 \\
\hline 4 & 191.131 & 270.198 \\
\hline 5 & 229.112 & 281.788 \\
\hline
\end{tabular}

\begin{tabular}{|c|c|c|}
\hline 6 & 275.788 & 282.327 \\
\hline 7 & 284.378 & 277.990 \\
\hline 8 & 305.985 & 333.066 \\
\hline 9 & 326.890 & 230.218 \\
\hline 10 & 329.537 & 306.594 \\
\hline 11 & 319.446 & 126.380 \\
\hline 12 & 268.918 & 265.918 \\
\hline
\end{tabular}

Tabel 2. Ramalan 2019 dan data actual real metode Exponential Smoothing 0.2

\begin{tabular}{|l|c|c|}
\hline no & $\begin{array}{c}\text { Ramalan penjualan 2019 } \\
\text { menggunakan data 2018 }\end{array}$ & $\begin{array}{c}\text { Data penjualan } \\
2019 \text { real }\end{array}$ \\
\hline 1 & 268.351 & 194.767 \\
\hline 2 & 158.717 & 210.460 \\
\hline 3 & $160.492,4$ & 206.017 \\
\hline 4 & $177.810,32$ & 270.198 \\
\hline 5 & $196.780,25$ & 281.788 \\
\hline 6 & $218.948,60$ & 282.327 \\
\hline 7 & $229.729,48$ & 277.990 \\
\hline 8 & $251.279,78$ & 333.066 \\
\hline 9 & $275.091,22$ & 230.218 \\
\hline 10 & $276.231,58$ & 306.594 \\
\hline 11 & $282.427,26$ & 126.380 \\
\hline 12 & $269.692,4$ & 265.918 \\
\hline
\end{tabular}

Tabel 3. Ramalan 2019 dan data actual real metode Exponential Smoothing 0.5

\begin{tabular}{|c|c|c|}
\hline no & $\begin{array}{c}\text { Ramalan penjualan 2019 } \\
\text { menggunakan data 2018 }\end{array}$ & $\begin{array}{c}\text { Data penjualan } \\
\text { 2019 real }\end{array}$ \\
\hline 1 & 244.193 & 194.767 \\
\hline 2 & 158.717 & 210.460 \\
\hline 3 & 163.155 .5 & 206.017 \\
\hline 4 & 205.118 .75 & 270.198 \\
\hline 5 & 238.889375 & 281.788 \\
\hline 6 & 273.255 .6875 & 282.327 \\
\hline 7 & 273.054 .3438 & 277.990 \\
\hline 8 & 305.267 .6719 & 333.066 \\
\hline 9 & 337.802 .3359 & 230.218 \\
\hline 10 & 309.297 .668 & 306.594 \\
\hline 11 & 308.253 .834 & 126.380 \\
\hline 12 & 263.503 .417 & 265.918 \\
\hline
\end{tabular}

a. Metode Single Moving Average tahun 2019

1. Mean Forecast Error (MFE) $=$ 2180.777

2. Mean Absolute Error $(M A E)=50250$

3. Mean Squared Error $(M S E)=$ 4164474008

4. Mean Absolute Percentage Error $=$ $25 \%$

b. Metode Exponential Smoothing alpha 0.2 tahun 2019 
1). Mean Forecast Error 22466,59313

2). Mean Absolute Error 22466,59313

3). Mean Absolute Error 5552225874

4). Mean Absolute Percentage Error 2\%

c. Metode Exponential Smoothing alpha 0.5 tahun 2019

1). Mean Forecast Error 7542.723455

2). Mean Absolute Error 7542.723455

3). Mean Square Error 625819448.3

4). Mean Absolute Percentage 4\%

\section{Daftar Pustaka}

Assauri, Sofyan. 1984. Teknik dan Metode Peramalan. Penerbit Fakultas Ekonomi Universitas Indonesia: Jakarta

Aritonang,Vicktor. 2009. Evaluasi Pengendalian Kualitas Produk Air Minum Dalam Kemasan (AMDK) dan Air Minum Isi Ulang (Refill) Di Kabupaten Sleman. Yogyakarta :Universitas Islam Indonesia

Bowerman, B. L. \& O'Connell, R.T. (1987). Time

Series Forecasting. Boston: Duxbury Press.

Hamka . (2013). Peramalan penjualan roti kenari arjuns bakery di kita Ternate provinsi Maluku Utara

Haryadi. irwan . (2013) Prediksi jumlah tamu menginap di hotel karlita international, tegal, jawa tengah

Herjanto (2009), Manajemen Operasi dan Produksi. Grasindo, Jakarta.

Heizer, J., Rander, B. (2006). Manajemen Operasi. Judul Asli: Operation Management, diterjemahkan oleh: Dwianoegrahwati dan Indra Almadhy. Buku 1. Edisi ketujuh. Jakarta: Salemba Empat.

Iwan, Agus, Eneng (2018) Analisa peramalan permintaan mobil Mitsubishi Xpander dengan tiga Metode Forecasting

J. Jonnius, (2012) Analisis forecasting penjualan produk perusahaan

Kartini, Puspatika. (2018) Peramalan harga cabai dengan metode Arima Arch Garch dan Single Moving Average di kota Semarang.

Kurniawan, M. F. A, dan U. Wiwi. 2013. Analisis Kapasitas Mesin Untuk Mengantisipasi Perkembangan Permintaan Produk Benang Dengan Metode Rccp (Rought Cut Capacity Planning). Jurnal Teknik Mesin, 2(1) : 86-93.

LM. Tanjung (2017). Perhitungan peramalan pengadaan obat menggunakan metode single exponential smoothing dan single moving average pada unit farmamin dinas kesehatan provinsi jawa tengah.
M. Nasution (2005). Total Quality Management, PT Gramedia Pustaka Utama: Jakarta

Makridakis, S., Wheelright, S.C., \& McGee, V. E. (1999). Metode dan Aplikasi Peramalan, (U.S. Andriyanto dan A. Basith, terj.). Jakarta: Erlangga.

Malikus, Saleh. (2015). Analisis peramalan air minum dalam kemasan pada PT. XYZ dengan metode least square dan standar error of estimate. Journal Industrial Engineering, 4 (1), 42-27

Munawar, A. 2003. Penerapan Metode Peramalan Penjualan Sebagai Dasar Penetapan Rencana Produksi (Studi Kasus di PT Varia Industri Tirta). Jurnal Ilmiah Kesatuan, 12(4) : 1-6.

Prasetio. (2014). Inventory Control Using Statistics Forecasting On Manufacture Company. Jurnal Informatika. Vol. II No. 2, September 2014.

Rachman, Rizal. (2018). Penerapan Metode Moving Average dan Exponential Smoothing pada Peramalan Produksi Industri Garment. Journal Informatika, 5 (1), 211-220

Rizal, (2018) Penerapan Metode Moving Average dan Exponential Smoothing pada Peramalan Produksi Industri Garment

Silitonga, Sinta (2009). Analisis peramalan pemakaian obat antibiotic golongan BLaktam di puskesmas gedong air. Bandar Lampung : Universitas Tulang Bawang

Sutrisno, Totok. 2010. Teknologi Penyediaan Air Bersih. Jakarta : Rineka Cipta

Syah, (2015) Analisis permintaan air minum dalam kemasan pada PT.XYZ dengan metode Least Square dan standard of estimate

Vincent Gaspersz. 2002. Production Planing and Inventory Control. PT. Gramedia Pustaka Utama: Jakarta

Wardah, Siti. (2016). Analisis peramalan penjualan produk kripik pisang kemasan bungkus. Journal Teknik Industri, 10 (23), 135-136

Wardani. (2015) Peramalan penjualan elektronik menggunakan metode single exponential smoothing dan double exponential smoothing pada toko lina mandiri elektronik cunda 
